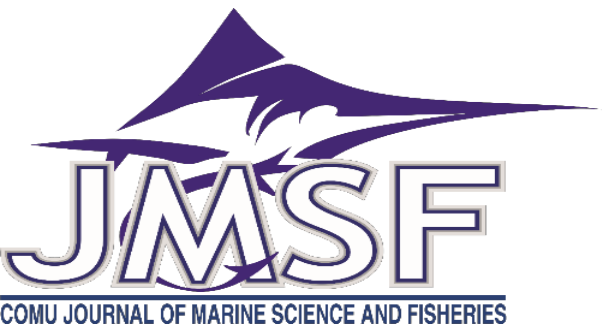

\title{
The Growth and Survival of Carpet Clam, Ruditapes decussatus in Çardak Estuary (Çanakkale Strait, Northwest Turkey)
}

\author{
Hakan Erdal, Umur Önal* \\ Çanakkale Onsekiz Mart University, Faculty of Marine Sciences and Technology, \\ Department of Aquaculture, Çanakkale, 17100, Turkey \\ Correspondent: umuronal@yahoo.com \\ Received: 06.11.2020 Accepted: 01.12.2020 \\ Umur Önal: Orcid 0000-0003-3588-8284
}

How to cite this article: Erdal, H. \& Önal, U., (2020). The growth and survival of Carpet clam, Ruditapes decussatus in Çardak estuary (Çanakkale Strait, Northwest Turkey). COMU J. Mar. Sci. Fish, 3(2): 120-129. DOI: 10.46384/jmsf.822386

\begin{abstract}
The growth and survival potential of the carpet clam, Ruditapes decussatus, in Çardak estuary (Northwest Turkey) were investigated. Clams were grown in 3 different locations with different substrate characteristics. Results indicated that clams grown in larger size substrate (Station C) composed of $38.41 \%$ cobble, $21.90 \%$ pebble and $17.16 \%$ granule by weight had higher growth and survival compared to those grown in substrates composed of smaller size fractions. Clams planted with a mean length and wet weight of $2.772 \mathrm{~cm}$ and $4.032 \mathrm{~g}$, reached a mean length and wet weight of $3.614 \mathrm{~cm}$ and $9.179 \mathrm{~g}$ at the end of 10 months. Transportation before planting had considerable effect on clam survival. In addition, mortality rates during summer were considerably higher in all stations than other seasons. Although the mean growth and survival rates of clams observed were similar to previously reported values, high summer mortality remains to be the most important factor for further investigations.
\end{abstract}

Keywords: European Little Neck Clam, Substrate, Mediterranean, Lagoon

\section{Çardak Lagünü’nde (Çanakkale Boğazı, Kuzeybatı Türkiye) Akivadesin, Ruditapes decussatus, Büyüme ve Hayatta Kalması}

Özet: Bu çalışmada akivadesin Ruditapes decussatus Çardak Lagünü’nde (Kuzeybatı Türkiye) büyüme ve hayatta kalma potansiyeli incelenmiştir. Kum midyeleri farklı substrat özelliklerine sahip 3 istasyonda büyütülmüştür. Sonuçlar, $38.41 \%$ iri çakı1, $21.90 \%$ çakıl ve $17.16 \%$ granülden oluşan C istasyonunda yetiştirilen akivadeslerin, daha küçük tanecik kompozisyonuna sahip diğer istasyonlara göre daha fazla büyüme ve hayatta kalma sergilediklerini göstermiştir. Başlangıç boy ve ağırlıkları sırasıyla, 2,772 cm ve 4,032 g olan akivadeslerin 10 aylık çalışma sonunda, ortalama $3,612 \mathrm{~cm}$ boy ve $9,179 \mathrm{~g}$ ağırlığa ulaştıkları tespit edilmiştir. Ekim öncesi yapılan taşımanın akivadeslerin hayatta kalma oranını etkilediği gözlenmiştir. Çalışmada tespit edilen büyüme ve hayatta kalma oranları diğer çalışmalarla benzerlik gösterse de, yazın gözlenen yüksek mortalite, bundan sonra yapılacak çalışmalar için en önemli konulardan bir tanesidir.

Anahtar Kelimeler: Avrupa Küçük Boyunlu Kum Midyesi, Substrat, Akdeniz, Lagün

\section{Introduction}

The carpet clam, Ruditapes decussatus, is a commercially important species throughout the Mediterranean and the European coasts. It is produced mainly in Italy followed by Portugal, France and
Spain. However, natural populations of this species are in decline due to a variety of reasons including over exploitation, diseases, habitat destruction and spread of invasive species such as $R$. philippinarum (Mathias, Joaquim, Matias, Paula, de Sousa, Sobral \& Leitão, 
2013). Despite its economic potential, information on the growth and survival of this species in estuaries along the Turkish coasts is scarce. Estuaries are important habitats for this species as they provide shelter and food. There is limited information about the growth and survival rates of carpet shell clams in Turkish waters especially in their natural habitats where they form large populations. Due to the dynamic nature of and unique characteristics of each estuary, information on the growth and survival of the carpet clam is important to exploit its aquaculture potential.

This study aims to determine the growth and survival of $R$. decussatus in Çardak estuary, which is one of the most important natural habitats for this species in the Çanakkale strait.

\section{Material and Methods}

\section{Determination of Clam Growth in Çardak Estuary}

The study was carried out in Çardak estuary, Çanakkale, Turkey (Fig. 1). The growth and survival of $R$. decussatus were determined in 3 different locations in Çardak Estuary, Çanakkale. The suitability of these stations for clam growth was investigated earlier for a period of 1 year as part of a project (TÜBİTAK 105Y103). The pre-selected stations (SA, SB and SC) had similar physicochemical parameters but differed with regard to sediment characteristics (Table 1). SA and SB were sand substrates and differed mainly by the ratio of different size fractions: SA was characterized mainly by coarse $(59.39 \%)$ and medium sand $(19.01)$, where as SB had $45.97 \%$ very coarse sand and $37.64 \%$ coarse sand by weight. Substrate in SC was mainly gravel and consisted $38.41 \%$ cobble, $21.90 \%$ pebble and $17.16 \%$ granule by weight (Table 1). Silt contents of all three stations were $<1 \%$.

Clams were obtained from Kutlukbey Corporation and following transportation kept in bags in seawater for 4 days before planting. Only live individuals were selected for planting. A total of 125 clams were randomly selected and measured for total length and total wet weight.

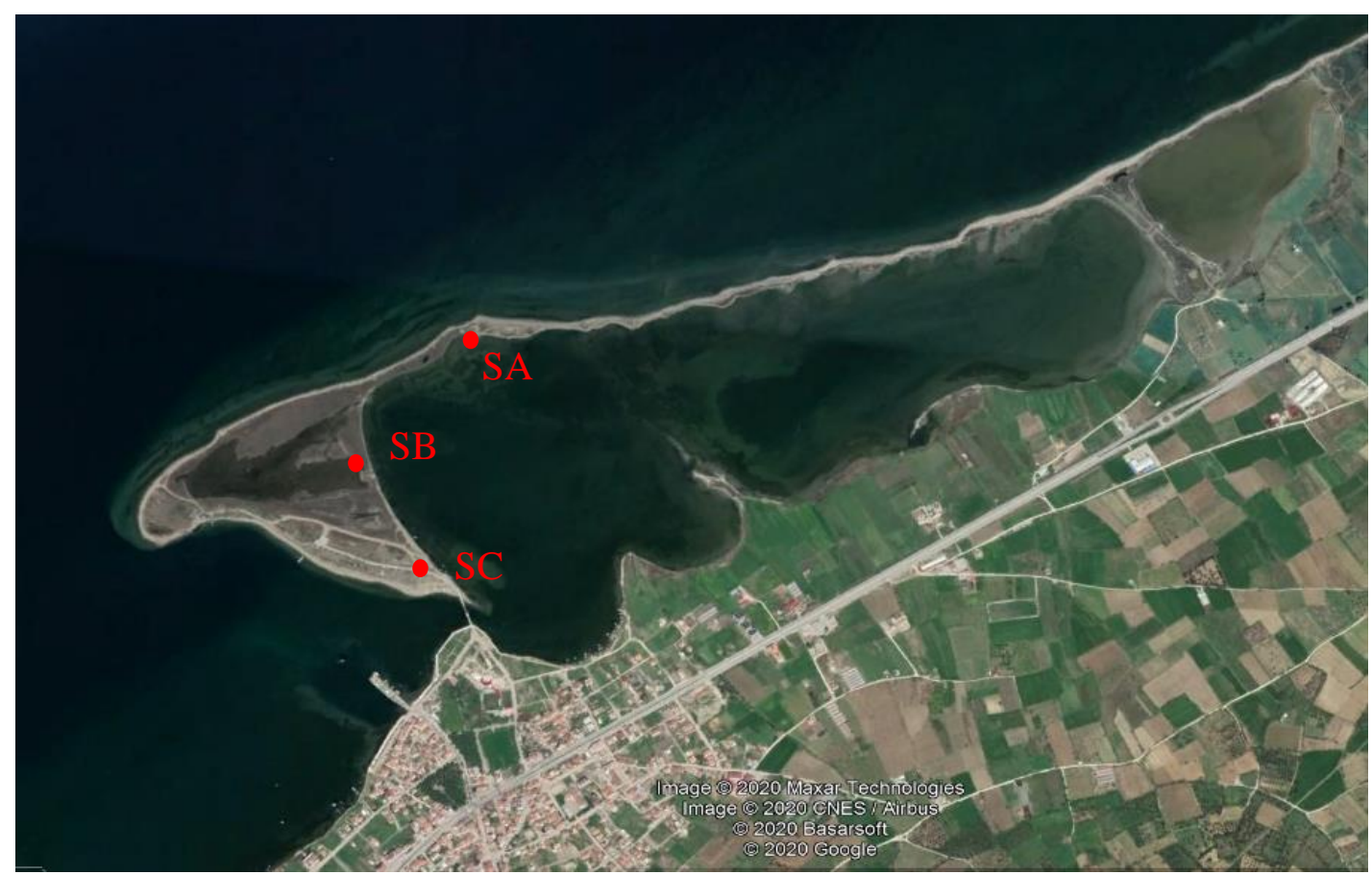

Figure 1. Satellite view of Çardak estuary and the locations of 3 stations. Locations of stations are indicated in red circles.

\section{Experimental Design}

For growth trials $100 \times 100 \times 20 \mathrm{~cm}$ wooden boxes with a total area of $1 \mathrm{~m}^{2}$ were used. Boxes were submerged into the substrate by removing a portion of the substrate with a shovel which was then refilled back. In order to prevent movement of cages by wave action, $2 \mathrm{~m}$ long iron bars were used to secure the boxes in place from each corner. Boxes were aligned along a straight line next to each other. A total of 300 clams were placed in each box with 5 replicates for each station. A total of 1500 clams corresponding to 300 clams $/ \mathrm{m}^{2}$ were planted to each station. All cages were allowed a break in period of 10 days before stocking with clams. After plantation, all boxes were covered with a nylon anti-predator net having a mesh size of 1 $\mathrm{cm}$. 
Table 1. Sediment characteristics of 3 stations (SA, SB and SC) based on Wenworth scale

\begin{tabular}{llcccc}
\hline \multirow{2}{*}{ Sediment type } & Size class & $\begin{array}{c}\text { Mesh size } \\
(\mathbf{m m})\end{array}$ & \multicolumn{3}{c}{ \% Weight mean } \\
\cline { 4 - 6 } Gravel & Cobble & $8-16$ & 0.68 & 0.26 & 38.41 \\
& Pebble & 4 & 1.94 & 2.79 & 21.90 \\
& Granule & 2 & 3.15 & 5.61 & 17.16 \\
\multirow{3}{*}{ Sand } & Very coarse sand & 1 & 10.59 & 45.97 & 12.23 \\
& Coarse sand & 0.5 & 59.39 & 37.64 & 6.27 \\
& Medium sand & 0.25 & 19.01 & 7.39 & 3.21 \\
& Fine sand & 0.125 & 3.95 & 0.26 & 0.74 \\
& Very fine sand & 0.063 & 0.95 & 0.07 & 0.05 \\
& Silt & $<0.063$ & 0.34 & 0.00 & 0.03 \\
\hline
\end{tabular}

\section{Experimental Design}

For growth trials $100 \times 100 \times 20 \mathrm{~cm}$ wooden boxes with a total area of $1 \mathrm{~m}^{2}$ were used. Boxes were submerged into the substrate by removing a portion of the substrate with a shovel which was then refilled back. In order to prevent movement of cages by wave action, $2 \mathrm{~m}$ long iron bars were used to secure the boxes in place from each corner. Boxes were aligned along a straight line next to each other. A total of 300 clams were placed in each box with 5 replicates for each station. A total of 1500 clams corresponding to 300 clams $/ \mathrm{m}^{2}$ were planted to each station. All cages were allowed a break in period of 10 days before stocking with clams. After plantation, all boxes were covered with a nylon anti-predator net having a mesh size of 1 $\mathrm{cm}$.

The growth and survival rates of clams were determined every 2 months for a period of 10 months. Growth was monitored by randomly selecting 30 clams from each cage. Mortality rates of clams were determined by counting number of dead clams as indicated by empty shells. Environmental parameters including temperature, salinity, dissoved oxygen, $\mathrm{pH}$ and chlorophyll-a were monitored every 2 weeks. Growth trial started in November 2006 and ended in September 2007.

Macroalgae growth over the cages were also monitored and cleaned periodically to prevent any potential negative effects on water renewal, particularly during summer.

Specific growth of clams was determined by the following:

$$
\mathrm{G}_{\mathrm{L}}: 100 \times\left(\operatorname{lnL}_{2}-\operatorname{lnL}_{1}\right) /\left(\mathrm{t}_{2}-\mathrm{t}_{1}\right)
$$

$\mathrm{L}_{1}$ : Initial length, $\mathrm{L}_{2}$ : Final length, $t$ : experimental duration in days

$$
\mathrm{G}_{\mathrm{w}}: 100 \times\left(\ln \mathrm{W}_{2}-\ln \mathrm{W}_{1}\right) /\left(\mathrm{t}_{2}-\mathrm{t}_{1}\right)
$$

$\mathrm{W}_{1}$ : Initial weight, $\mathrm{W}_{2}$ : Final weight, $t$ : experimental duration in days

\section{Statistical analysis}

Data on the growth and survival rates of clams were analyzed by ANOVA. Differences in growth and survival among stations were compared using Tukey's HSD multiple range test $\mathrm{P}<0.05$ ).

\section{Results}

\section{Environmental Parameters}

Temperature, salinity, $\mathrm{DO}$ and $\mathrm{pH}$ values during the experimental period are given in Figures 2-6. Overall, temperatures were similar in all stations throughout the year (Fig. 2). Minimum temperature was recorded as $7.16{ }^{\circ} \mathrm{C}$ in SB in January and the maximum temperature was recorded as $29.87^{\circ} \mathrm{C}$ in SA in August. The lowest temperature was $7.16{ }^{\circ} \mathrm{C}$ in SB in December. The temperature in SA was slightly higher $\left(0.5-1.0^{\circ} \mathrm{C}\right)$ than those of the other stations between January-March. Temperatures started to increase considerably in April and this trend continued until the end of August. Salinity was relatively stable throughout the growing trial and ranged between 24.30 and 28.02 ppt (Fig 3). As expected, salinity in $\mathrm{SC}$ was slight lower during summer as it was closer to the mouth of the estuary.

DO levels in Çardak estuary increased until March (Fig. 4). Oxygen levels reached to supersaturated levels in February-April. DO levels dropped after May which coincided with elevated temperatures above $20{ }^{\circ} \mathrm{C}$ with a slight increasing trend observed after June. Minimum DO concentration was $4.96 \mathrm{mg}$ $\mathrm{L}^{-1}$ in May, 25th, in SB. No significant pattern was observed among stations with respect to DO levels. In 
all stations $\mathrm{pH}$ levels were consistently similar except in May, when $\mathrm{pH}$ level in SB was 7.52 (Fig. 5). Highest pH level was 9.27 in April in SC.

Chlorophyll-a levels had higher variations among stations compared to other parameters but showed a distinct pattern characterized by lower values in the winter and spring and an increasing trend in the summer. Chlorophyll-a levels ranged between 0.011$9.999 \mu \mathrm{g} \mathrm{L}^{-1}$ and stations did not differ with respect to chlorophyll-a levels throughout the study.

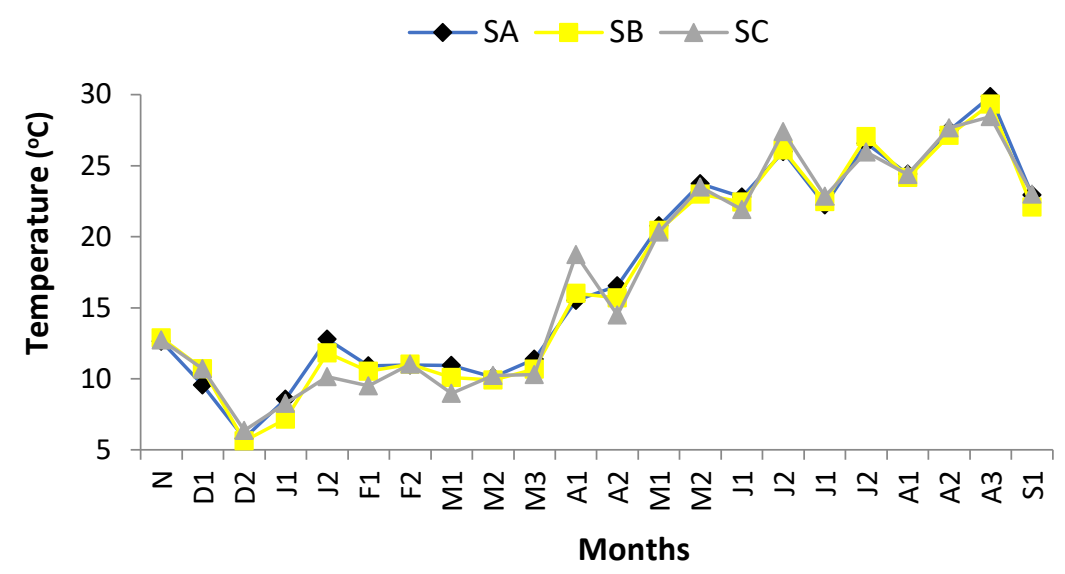

Figure 2. Changes in temperature during November-September period in 3 different stations

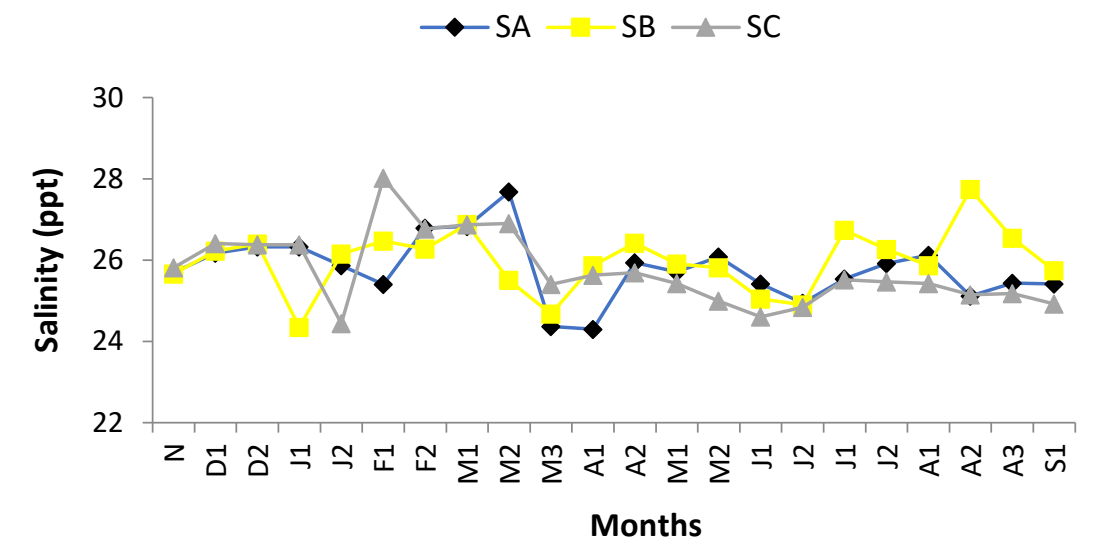

Figure 3. Changes in salinity during November-September period in 3 different stations

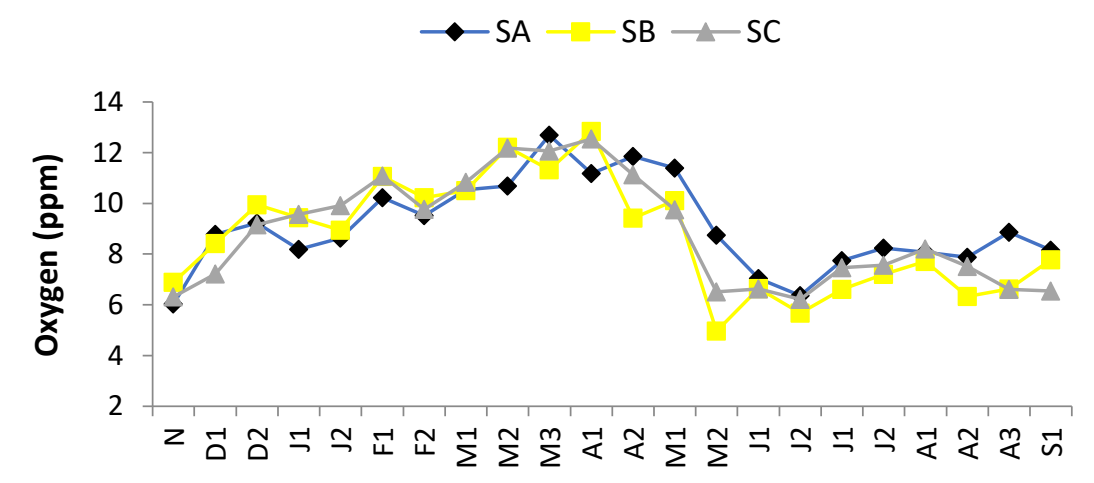

\section{Months}

Figure 4. Changes in dissolved oxygen during November-September period in 3 different stations 


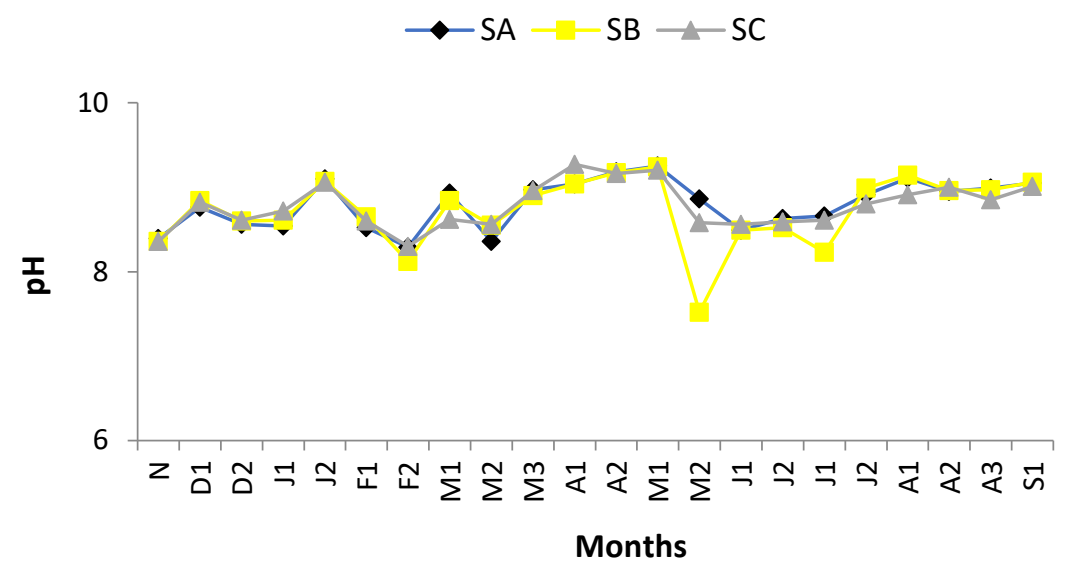

Figure 5. Changes in $\mathrm{pH}$ during November-September period in 3 different stations

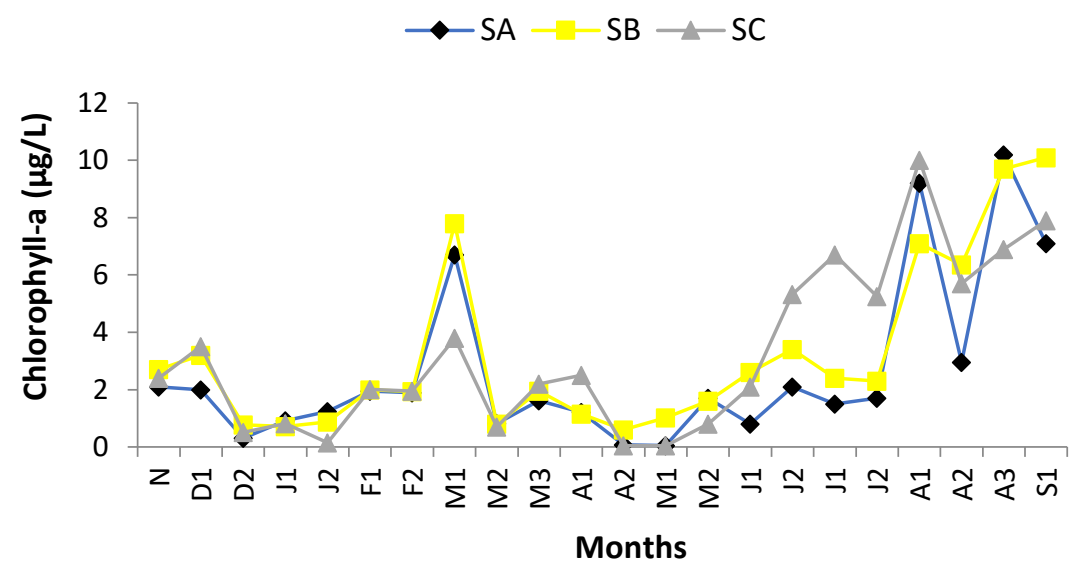

Figure 6. Changes in chlorophyll-a during November-September period in 3 different stations

\section{Growth and Survival Rates of Clams}

The initial length and weight of clams were 2.772 $\mathrm{cm}$ ve $4.032 \mathrm{~g}$, respectively. At the end of 10 months, the mean length and wet weight of clams were 3.614 $\mathrm{cm}$ and $9.179 \mathrm{~g}$, respectively (Table 2 and 3). After 10 months of growth period, total mean weight of clams in SC were $9.813 \mathrm{~g}$, followed by SB which was 9.097 g. SA had the lowest final mean weight of $8.626 \mathrm{~g}$.

Growth was slower in all stations during the winter (Fig. 7 and Fig 9). Clams in SA had the highest specific growth rate in January (Fig. 8 and Fig 10) but there were no differences in length and weight between stations $(p>0.05)$. Specific growth in length for SA, SB and SC were 0.058, 0.038, and 0.022, respectively (Fig 8). Specific growth in weight for SA, SB and SC were $0.172,0.146$, and 0.124 , respectively (Fig 10).

In all stations, growth in March was still low (Fig 7 and Fig 9). SC had the highest growth rate and SB had the lowest growth rate. In May, there were no significant differences in mean length and weight among stations and growth rate was low in all stations $(\mathrm{p}>0.05)$.

Growth rate in July was considerably higher in all stations (Fig 7 and Fig 9). Specific growth rates in SA, SB and SC were $0.132,0.112$, and 0.226 , respectively. Increase in length and weight of clams was higher in $\mathrm{SC}$, which was significantly higher than those in other stations $(\mathrm{p}<0.05)$.

Growth rate in September was similar to that observed in July. SC had a higher growth rate compared to those in other stations (Fig. 7). The highest growth in length and weight was observed in SB. Specific growth rates in length were $0.164,0.251$, 0.153 for SA, SB and SC, respectively.

Mortality rates were relatively high in November after transplantation but were similar in all stations (Fig 11.) There were significant differences in mortality rates among stations after January. While SA had the highest mortality rates with $7.2 \%$, those of SC and SB were 1.4 and $0.4 \%$, respectively (Fig 11). Mortality rates were considerably lower in all stations in March and SA had the highest mortality rate which 
was significantly higher than those of other stations. In May, mortality rate was higher in SA than those of other stations. In July, despite increases in growth rate, mortality was higher in all stations and SA had the highest mortality rate with $33.2 \%$ during this period. Similar to previous seasons, in September, highest mortality rate was observed in SA (Fig 11).

Table 2. Changes in lengths of carpet shell clams (cm) in Çardak estuary during November 2006-September 2007

\begin{tabular}{lcccccc}
\hline & \multicolumn{5}{c}{ Months } \\
\cline { 2 - 6 } Station & November & January & March & May & July & September \\
\hline SA & $2.772 \pm 0.03$ & $2.871 \pm 0.74$ & $2.888 \pm 0.74$ & $2.930 \pm 0.84$ & $3.172 \pm 0.96$ & $3.499 \pm 0.88$ \\
SB & $2.772 \pm 0.03$ & $2.836 \pm 0.64$ & $2.873 \pm 0.74$ & $2.935 \pm 0.66$ & $3.139 \pm 0.97$ & $3.650 \pm 0.69$ \\
SC & $2.772 \pm 0.03$ & $2.809 \pm 0.50$ & $2.887 \pm 0.31$ & $2.940 \pm 0.29$ & $3.368 \pm 0.98$ & $3.693 \pm 0.30$ \\
Mean & $\mathbf{2 . 7 7 2} \pm \mathbf{0 . 0 0}$ & $\mathbf{2 . 8 3 9} \pm \mathbf{0 . 0 3}$ & $\mathbf{2 . 8 8 3} \pm \mathbf{0 . 0 1}$ & $\mathbf{2 . 9 3 5} \pm \mathbf{0 . 0 1}$ & $\mathbf{3 . 2 2 6} \pm \mathbf{0 . 1 2}$ & $\mathbf{3 . 6 1 4} \pm \mathbf{0 . 1 0}$
\end{tabular}

Table 3. Changes in weight of carpet shell clams (g) in Çardak estuary during November 2006 - September 2007

\begin{tabular}{lcccccc}
\hline & \multicolumn{5}{c}{ Months } \\
\cline { 2 - 7 } Station & November & January & March & May & July & September \\
\hline SA & $4.032 \pm 0.70$ & $4.471 \pm 0.40$ & $4.760 \pm 0.30$ & $4.777 \pm 0.47$ & $6.395 \pm 0.57$ & $8.626 \pm 0.79$ \\
SB & $4.032 \pm 0.70$ & $4.402 \pm 0.17$ & $4.475 \pm 0.36$ & $4.818 \pm 0.30$ & $5.730 \pm 0.57$ & $9.097 \pm 0.40$ \\
SC & $4.032 \pm 0.70$ & $4.344 \pm 0.19$ & $4.696 \pm 0.26$ & $4.852 \pm 0.16$ & $7.802 \pm 0.98$ & $9.813 \pm 0.43$ \\
Mean & $\mathbf{4 . 0 3 2} \pm \mathbf{0 . 0 0}$ & $\mathbf{4 . 4 0 6} \pm \mathbf{0 . 0 6}$ & $\mathbf{4 . 6 4 3} \pm \mathbf{0 . 1 5}$ & $\mathbf{4 . 8 1 6} \pm \mathbf{0 . 0 4}$ & $\mathbf{6 . 6 4 2} \pm \mathbf{1 . 0 6}$ & $\mathbf{9 . 1 7 9} \pm \mathbf{0 . 6 0}$ \\
\hline
\end{tabular}

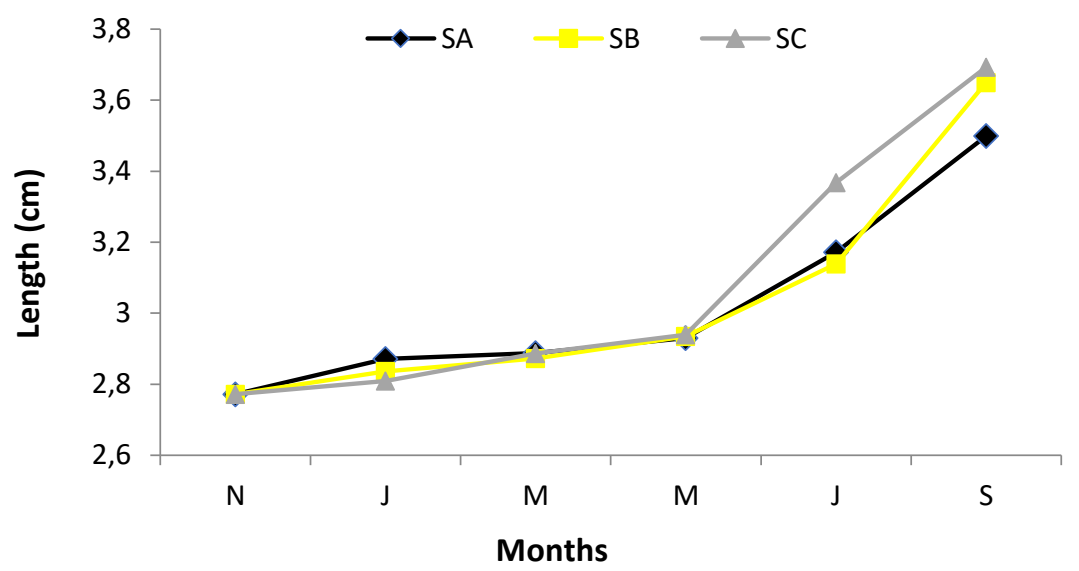

Figure 7. Changes in lengths of carpet shell clams (cm) in Çardak estuary between November 2006 - September 2007 


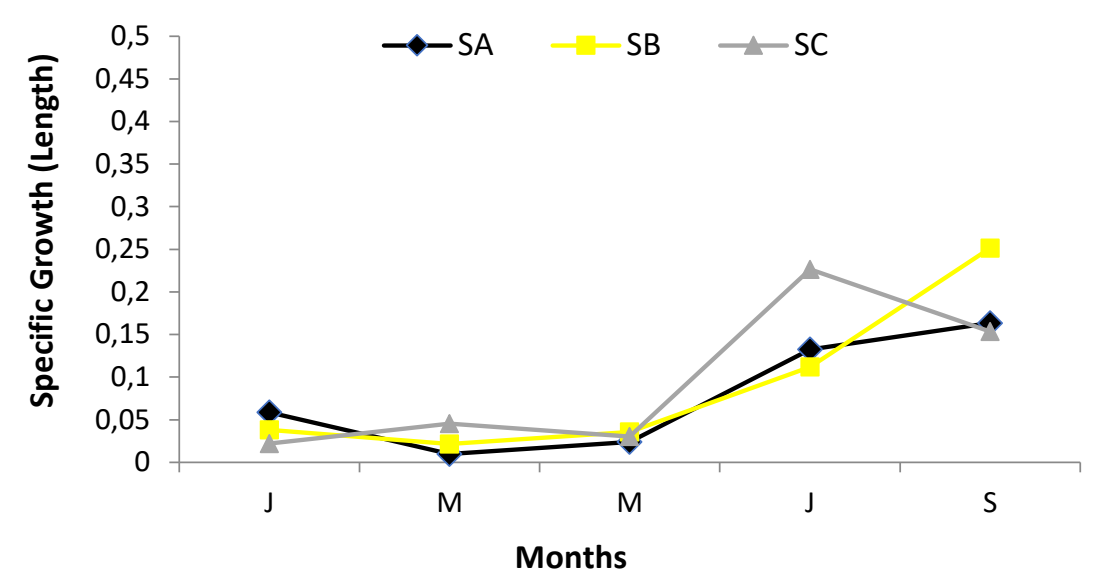

Figure 8. Changes in specific growth of carpet shell clams (length) in Çardak estuary between November 2006 - September 2007

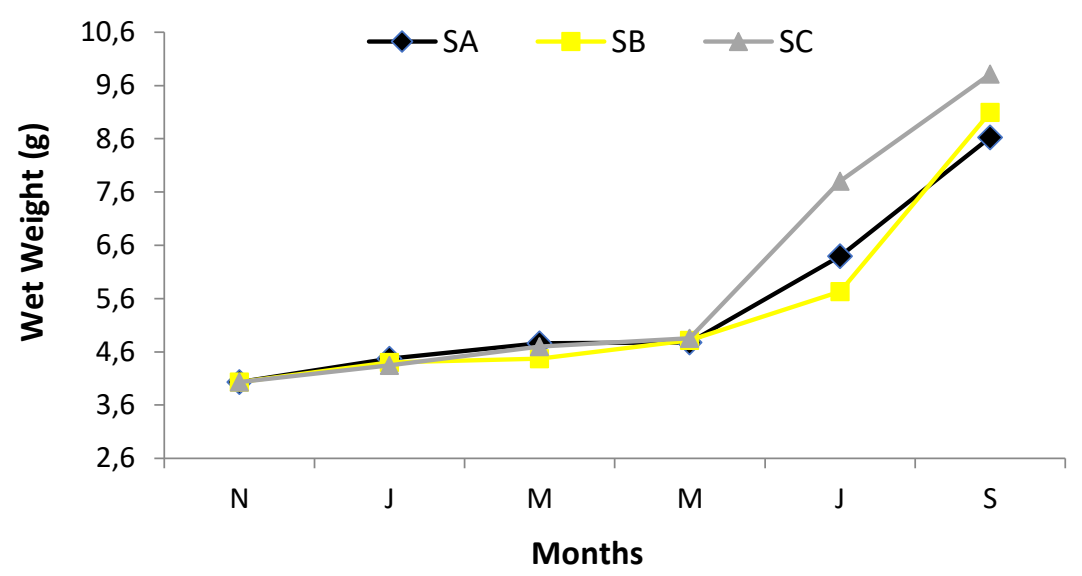

Figure 9. Changes in wet weights of carpet shell clams (g) in Çardak estuary between November 2006September 2007

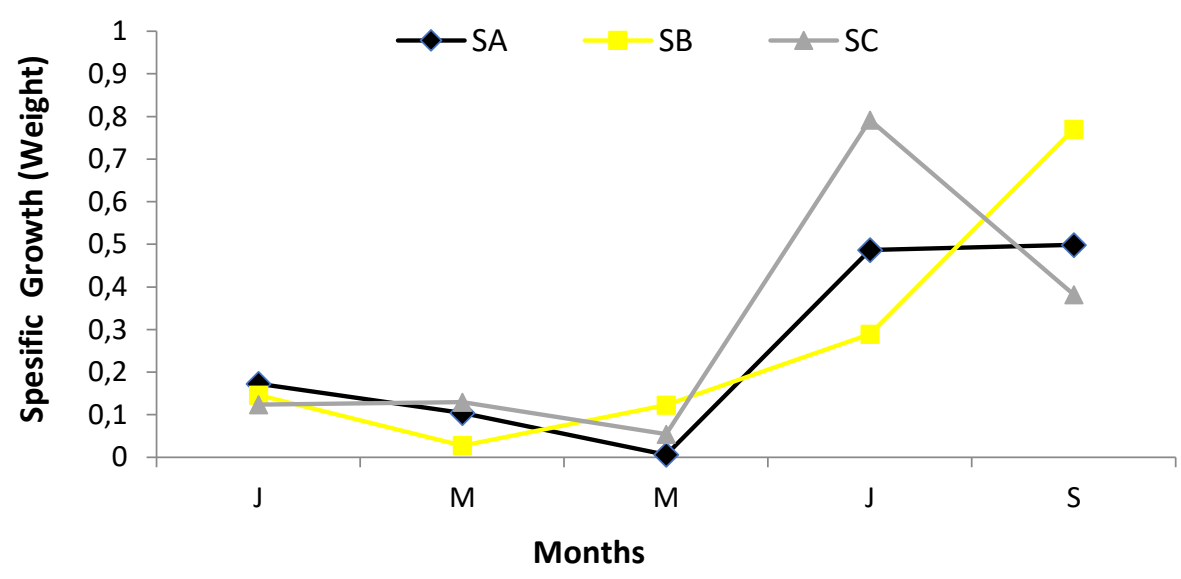

Figure 10. Changes in specific growth of carpet shell clams (weight) in Çardak estuary between November 2006-September 2007 


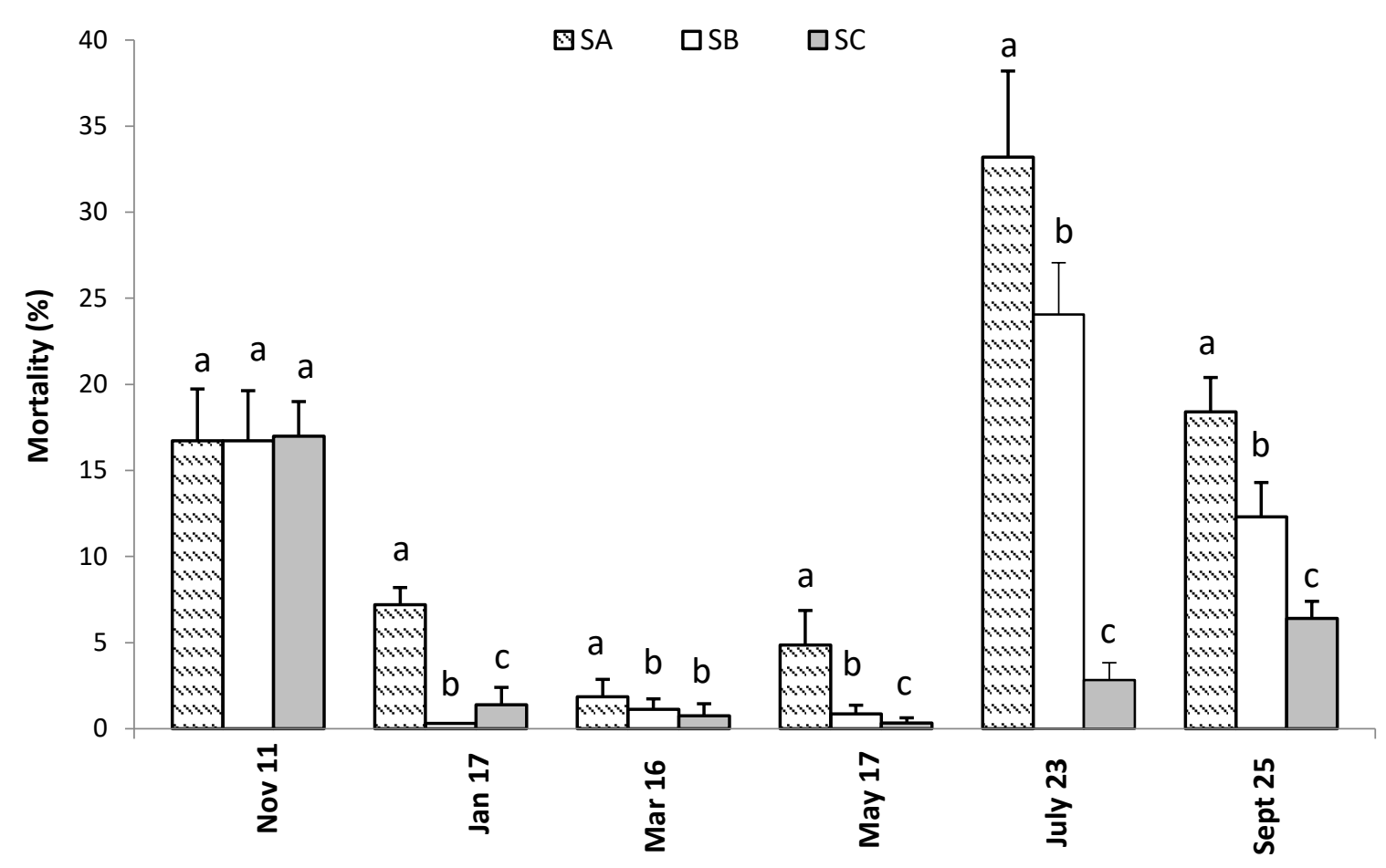

Figure 11. Seasonal mortality rates of clams in Çardak estuary between November 2006 - September 2007

\section{Discussion}

In this study, highest growth rate of clams was in summer and early fall. This is similar to findings of others (Breber, 1985; Serdar, Lök, Köse, Yıldız, Acarlı \& Goulletquer, 2007). Increase in growth rate during summer might be a factor of both temperature and food supply as indicated by chlorophyll-a levels which increased during summer in Çardak estuary. Overall, highest clam growth was in SC. However, in winter growth rate was higher in SA. This was possibly due to slightly higher temperatures $\left(0.5-1^{\circ} \mathrm{C}\right)$ in SC during this period. After April, temperature was relatively similar between stations. When the differences in temperature were below $0.5^{\circ} \mathrm{C}$ between stations, temperature was not a significant factor for differences observed in growth. In the present study, clam growth after 10 months corresponded to a mean growth of $9.664 \mathrm{~mm} /$ year $\left(27 \times 10^{-3} \mathrm{~mm} /\right.$ day $)$ and 5.908 gr/year (16.19 mg/day), in length and total weight, respectively. These findings are similar to those reported in earlier studies in Western Turkey (Serdar et al., 2007). However, higher and lower growth rates for carpet shell clams have been reported by other researchers (Laing, Utting \& Kilada, 1987; Puigcerver, 1996; Vilela, 1950; Walne, 1976). Such differences in growth rate is due to combination of a variety of factors including clam age, habitat characteristics, food type and concentration, environmental conditions, stocking rate and culture methods and reflects the intrinsic and dynamic nature of habitats in which clams are grown.

Higher growth rate observed in SC may be attributed to the substrate composition which consisted higher ratios of gravel. The effect of substrate quality on growth has been shown earlier. For example, Toba, Tompson, Chew, Anderson \& Miller (1991) stated that Manila clams, Ruditapes philippinarum, had higher growth rates in substrates composed of ground oyster shells. Similarly, Tapes dorsatus grown in substrate containing a mixture of sand-seashell $(50 \% / 50 \%$ by weight $)$ had higher growth rates compared to those grown in sand or mud subtrates (Paterson \& Nell, 1997). Lower growth rates in substrates containing higher silt and clay content was also reported for the hard clam, Mercanaria mercanaria (Craig \& Bright, 1986). It has been postulated that larger grain size substrate support clams in the sediment and prevent sinking in the substrate. In addition, it was reported that wave activity in estuaries may help suspend silt which in turn, impede filtration activity of clams and increase their energy demand (Paterson \& Nell, 1997). Increased levels of energy for maintenance will have negative effects on growth and survival and may also explain higher mortality rates observed in SA. Although water quality parameters in SA did not indicate any significant problems for clam growth, high mortality rates in summer remain to be a critical factor that needs to be addressed in future studies. 
In this study, although DO and salinity measurements indicated no limiting effect, the lack of continuous real-time on-site measurements may have prevented to shed light on limiting conditions when they occurred. Excessive macroalgae growth on antipredator nets may have resulted in reduced flow rates in SA and SB which, in turn, may have resulted in lower DO concentrations. Such adverse conditions would have minimum effect in SC due to its proximity to the mouth of estuary where a continuous current exists between the estuary and off-shore and may explain significantly higher survival rates in SC (72.28\%) compared to other stations. Growth limitations of clams as a result of macroalgae overgrowth in summer have also been reported previously by others (Breber, 1985). In the present study, the mean survival rate of clams was $44.4 \%$ at the end of 10 months. This survival rate was similar to other reported values. For example, Serdar et al. (2007) reported $48 \%$ survival rate for $R$. decussatus after 12 months in Homa estuary, İzmir, in western Turkey. Chessa, Paesanti, Pais, Scardi, Serra \& Vitale (2005) reported a survival rate of $50 \%$ for $R$. decussatus in Calich Estuary, Italy, at the end of 15 months. Typically, a 50\% survival rate was reported for manila clam juveniles until they reach commercial size in Italy (Sladonja, Bettoso, Zentilin, Tamberlich \& Acquavita, 2011).

Our findings indicated that, transportation is an important factor for clam mortality after planting. In the present study, predation by crabs, which is a major factor for clam mortality, did not contribute to observed mortality rates as indicated by the absence of crabs underneath the nets during regular periodic maintenance of wooden boxes. Although the mean survival rate of clams observed was similar to other studies, high summer mortality remains to be the most important factor for further investigations.

Clam density is another important factor that affects growth rate (Jara Jara, Pazos, Abad, GarciaMartin \& Sanchez, 1997). In the present study, 300 clams $/ \mathrm{m}^{2}$ corresponding to an initial mean biomass of $1.210 \mathrm{~kg} / \mathrm{m}^{2}$ reached a final mean biomass of 1.223 $\mathrm{kg} / \mathrm{m}^{2}$ at the end of 10 months considering a mean survival rate of \%44.4. Clam density in the present study was higher than typical densities of 150 individuals $/ \mathrm{m}^{2}$ reported for manila clam in Italy (Sladonja et al., 2011). However, higher stocking densities of up to $1000 \mathrm{clams} / \mathrm{m}^{2}$ and $2.5 \mathrm{~kg} / \mathrm{m}^{2}$ were reported for growth trials (Breber, 1985; Jara Jara et al., 1997). In the present study, the area where the grow-out experiment was carried out is a commercially harvested site with a typical clam biomass of about $1.0 \mathrm{~kg} / \mathrm{m}^{2}$ (Önal, personal communication). Currently, extensive clam culture in Çardak estuary covers only a fraction $(<5 \%)$ of total estuary area and increase in chlorophyll-a values during summer when growth rate is maximum indicates food is not a limiting factor. Considering clam densities and total area of clam beds Çardak estuary may support higher clam yields.

In Turkey, there is no commercial clam aquaculture and clam production is limited to natural harvests. Transport of clam seed from productive sites to less exploited areas is extensively practiced by clam fisherman. However, success of these local efforts is not documented because a great majority of clam beds are located in public areas. The lack of hatchery seed production and suitable habitats for mass production are major factors that limit commercial operations. In addition, majority of estuaries in Turkey are subject to a variety of factors such as pollution, habitat degradation and over fishing that significantly limit their potential for clam aquaculture. Therefore, rehabilitation programs for estuaries should be directed towards maximizing their potential for clam aquaculture. In Çardak estuary, substrate modification of clam beds and increase rates of seawater exchange are required in order to increase clam production.

\section{Acknowledgements}

This research was founded by TUBITAK under grant number 105Y103. This study is part of Hakan Erdal's Master's thesis.

\section{References}

Breber, P. (1985). On-growing of the carpet shell clam, Tapes decussatus (L): Two years experience in Venice Lagoon. Aquaculture, 44, 51-56.

Chessa, L.A., Paesanti, F., Pais, A., Scardi, M., Serra, S., \& Vitale, L. (2005). Perspectives for development of low impact aquaculture in awestern Mediterranean lagoon: the case of the carpet clam Tapes decussatus. Aquaculture Int., $13,147-155$.

Craig, M.A., \& Bright, T.J. (1986). Abundance, age distribution and growth of the Texas hard clam, Mercanaria mercanaria texana, in Texas bays. Contributions in Marine Science, 29, 59-72.

Jara-Jara, R., Pazos, A.J., Abad, M., Garcia-Martin, L.O., \& Sanchez, J.L. (1997). Growth of clam seed (Ruditapes decussatus) reared in the wastewater effluent from a fish farm in Galicia (N. W. Spain). Aquaculture, 158, 247-262.

Laing, I., Utting, S.D., \& Kilada, R.W. (1987). Interactive effects of diet and temperature on the growth of juvenile clams. Journal of Experimental Marine Biology and Ecology, 113, 23-38.

Mathias D., Joaquim S., Matias A. M., Paula M., de Sousa J.T., Sobral, P., \& Leitão, A. (2013). The reproductive cycle of the European clam Ruditapes decussatus (L., 1758) in two Portuguese populations: Implications for management and aquaculture programs. Aquaculture, 406-407, 5261. 
Paterson, K.J., \& Nell, A.J. (1997). Effect of different growing techniques and substrate types on the growth and survival of the clams Tapes dorsatus (Lamarck) and Katelysia rhytiphora (Lamy). Aquaculture Research, 28, 707-715.

Puigcerver, M. (1996). Analysis on individual growth of juvenile carpet shell clams, Tapes decussatus (L.), in three different rearing conditions employed in the Ebro's Delta, Spain. Aquaculture Research, 27, 399-404.

Serdar, S., Lök, A., Köse, A., Yıldız, H., Acarlı, S., \& Goulletquer, P. (2007). Growth and survival rates of carpet Shell clam (Tapes decussatus, Linnaeus 1758 using various culture methods in Sufa (Homa) lagoon, İzmir, Turkey. Aquacultural Engineering, 37, 89-99.

Sladonja, B., Bettoso, N., Zentilin, A., Tamberlich, F., \& Acquavita, A. (2011). Manila Clam (Tapes philippinarum Adams \& Reeve, 1852) in the Lagoon of Marano and Grado (Northern Adriatic Sea, Italy): Socio-Economic and Environmental Pathway of a Shell Farm. In B. Sladonja (Ed), Aquaculture and the Environment: A Shared Destiny (pp. 52-78): In Tech Croatia.

Toba, D.R., Tompson, D.S., Chew, K.K., Anderson, G.J., \& Miller, M.B. (1992). Guide to Manila Clam Culture in Washington. Sea Grant Programme, University of Washington, Seattle, WA, USA, p. 80 .

Vilela, H. (1950). Vida Bentonica de Tapes decussatus (L.). Travaux de la Station de Biologie Maritime de Lisbonne, 53, 120 pp.

Walne, P.R. (1976). Experiments on the culture in the sea of the butterfish Venerupis decussata L. Aquaculture, 8, 371-381. 